\title{
Quantitative Evaluation of the Production of Ligninolytic Enzymes- Lignin Peroxidase and Manganese Peroxidase by P. Sajor Caju During Coir Pith Composting
}

\author{
*Radhakrishnan $\mathrm{S}^{1}$, Anita Das Ravindranath ${ }^{2}$, Hanosh M S ${ }^{3}$, Sarma U S $\mathrm{S}^{4}$ Jayakumaran Nair $\mathrm{A}^{5}$
}

\begin{abstract}
Coir is the natural hard fruit fibre extracted from the exocarp of the coconut. The fibre has over 40 percent lignin and is spun into yarn and rope. Coir is used globally for manufacturing floor coverings as home furnishing. The Coir Industry enjoys the status as the largest cottage industry in Kerala giving employment to over a million people, of which 80 percent constitute women. Coir pith is a biomass residue generated during the extraction of coir fibre from coconut husk. Coir pith produced during coir fibre extraction is of environmental concern as its dumping on shore line and leaching of its constituents alter water quality and aquatic life. Management of coir pith is a major problem with all coir industrialists. Hillocks of coir pith accumulate in the vicinities of coir fibre extraction units in Kerala, Tamil Nadu, Andhra Pradesh, Karnataka, and Orissa. These agricultural wastes have traditionally been disposed by burning which resulted in various environmental problems. Therefore, composting is an alternate way to dispose coir pith and is of critical importance. Ligninolytic enzyme production during coir pith composting by Pleurotus sajor caju has been studied in detail. Pleurotus sajor caju produces oxidative enzymes which degrade lignin in the presence of urea as nitrogen source. Substitution of urea with vegetative sources has resulted in the vigorous growth of the mushroom which leads to decreased lignin content and $\mathrm{C}$ : $\mathrm{N}$ ratio in the biodegraded coir pith. Combination of Azolla and Soya hulls as biological supplements was observed to be the best substitute for lignin peroxidase and manganese peroxidase production. Activity of manganese peroxidase and lignin peroxidase was maximum on the twentieth day of fermentation of coir pith. The level of enzyme activity during biological composting using vegetative sources was compared with the conventional process using urea. The enzyme profile exhibited variation with change in substrate and duration of decomposition. The colonization of Pleurotus sajor caju by its utilization leads to biochemical changes in coir pith converting it into an ideal plant nutrient.
\end{abstract}

Keywords: Coir pith, Lignocellulose, Recalcitrant, Pleurotus sajor caju, Composting, Solid state fermentation.

1,2,3 and ${ }^{4}$ Central Coir Research Institute (Coir Board), Alleppey, Kerala, ${ }^{5}$ Department of Biotechnology, Kariavattom, Thiruvananthapuram, Kerala, India.

*Corresponding author. Tel: 0477 - 2258480, 2258094, Fax: 0477- 2258415

Email address: rkharipad@gmail.com 


\section{Introduction}

Coir pith is a lignocellulosic biomass generated from the coir industry during the extraction of coir fibre and accumulates forming hillocks. The recalcitrant nature of coir pith is due to high percentage of lignin (Table 1). Coir industries and fibre extraction units contribute considerably to the problems of environmental pollution. Lignin polymers are major obstacle to the efficient utilization of lignocellulosic materials in a wide range of industrial processes. Lignin degradation is an energy consuming process that requires co-substrates in the fermentation medium. In natural substrate, cosubstrates are obtained by enzymatic polysaccharides [Pandey and Radhakrishnan., 1993]. White rot fungus, Pleurotus sajor caju is known to have evolved complex enzymatic machinery to degrade lignin, produce extra cellular polyphenol oxidases particularly lignin peroxidase and manganese peroxidase, which are highly effective in degrading lignin [Krik. and Farell, 1987]. So far a lot of work has been carried out to determine the relationship between changes of lignocellulose content and activity of P.sajor caju during solid state fermentation of coir pith. These studies were mainly on the enzyme production and the optimization control for lignocellulose removal. The biological decomposition of organic matter is mediated by a variety of biochemical processes in which enzymes play a key role. The degradation of major constituents like cellulose, hemicellulose and lignin (Table 2) present in coir pith is carried out by specific enzymes. Therefore, the quantification of enzyme activity during biodegradation of coir pith can reflect on the dynamics in terms of decomposition of organic matter and nitrogen transformation. It may also be helpful in providing information about the nutrient status of the composted product (Table 3). Though, extensive studies have been carried out on the physico chemical changes during degradation of coir pith, the information on the enzyme activity is rare. This paper evaluates the potential of coir pith as a substrate for ligninolytic enzyme production by Pleurotus sajor caju.

\section{Materials and Methods}

\section{Microorganism}

The white rot Basidiomycetes, Pleurotus sajor caju was collected from Central Coir Research institute (Coir Board), Alleppey, Kerala. The culture was maintained on Potato Dextrose Agar slants, stored at $15^{\circ} \mathrm{C}$ and sub cultured once a month. The microorganism was mass cultured on sterilized media consisting of sorghum mixed with $0.2 \%$ calcium carbonate as carbon source in polythene bags. Fully grown packets (400 gms) after 15 days of incubation were used for carrying out the experimental study on biodegradation of coir pith.

\section{Coir pith and biological supplements}

Coir pith used for carrying out this experiment was collected from a coir defibring unit at Kattukada, Cherthala in Alleppey District of Kerala. The biological nitrogen supplements viz., Azolla was collected from a nearby nursery and Soya hulls from Madurai, Tamil Nadu. All chemicals used for this study were of analytical grade.

\section{Culture Conditions}

Experiment on biodegradation was carried out by laying coir pith heaps in shady open places. Coir pith was mounted in $5 \mathrm{~kg}$ heaps in triplicate and supplemented with a combination of Azolla and Soya hulls (2:1) ratio as nitrogen source to stimulate the secretion of extra cellular enzymes. A second set of coir pith heaps in triplicate was laid with urea as nitrogen source. Uninoculated coir pith was maintained as control. The experimental coir pith heaps were allowed to decompose for thirty days.

\section{Determination of lignin}

The Klason lignin in coir pith was determined by the following method [Moorthy, 1981]. Approximately one gram of coir pith was weighed out in triplicate in tarred weighing bottles and dried at $105^{\circ} \mathrm{C}$ for one hour. The material was weighed thrice till a constant weight (A) was obtained. The material was then carefully transferred to a clean filter paper and rolled to pack the contents. The three packed 
Table 1. Differential composition of various fractions of coir pith (\%)

\begin{tabular}{|l|c|c|c|}
\hline \multicolumn{1}{|c|}{ Parameter } & Fine coir dust & Coarse coir dust & Husk \\
\hline Moisture & 15.77 & 20.39 & 21.45 \\
\hline Organic matter & 86.87 & 96.43 & 96.54 \\
\hline Ash & 13.13 & 3.57 & 3.54 \\
\hline Nitrogen & 1.04 & 0.39 & 0.26 \\
\hline Phosphorous & 0.014 & 0.017 & 0.18 \\
\hline Potassium & 0.39 & 0.38 & 0.31 \\
\hline Lignin & 37.71 & 43.65 & 45.6 \\
\hline Pentosan & 11.95 & 13.10 & 19.15 \\
\hline Rate of pentosan to lignin & 0.32 & 0.30 & 0.42 \\
\hline
\end{tabular}

Source: Ghosh et al., 2007

Table 2. Chemical composition and physical properties of coir pith

\begin{tabular}{|c|l|c|c|}
\hline SI No & \multicolumn{1}{|c|}{ Constituents } & Unretted coir pith & Retted coir pith \\
\hline 1 & Lignin (\%) & 38.5 & 30 \\
\hline 2 & Cellulose (\%) & 26.40 & 25.10 \\
\hline 3 & Organic Carbon (\%) & 29.5 & 29.0 \\
\hline 4 & Nitrogen (\%) & 0.24 & 0.26 \\
\hline 5 & Phosphorous (\%) & 0.01 & 0.01 \\
\hline 6 & Potassium (\%) & 0.71 & 0.76 \\
\hline 7 & C:N ratio & $123: 1$ & $112: 1$ \\
\hline 8 & Calcium (\%) & 0.40 & 0.47 \\
\hline 9 & Magnesium (\%) & 0.36 & 0.41 \\
\hline 10 & Copper (ppm) & 3.10 & 4.20 \\
\hline 11 & Iron (ppm) & 0.07 & 0.08 \\
\hline 12 & Manganese(ppm) & 12.50 & 17.00 \\
\hline 13 & Zinc(ppm) & 7.50 & 9.80 \\
\hline 14 & Moisture (\%) & $20-30$ & $60-80$ \\
\hline 15 & pH & $5.4-5.8$ & $5.6-6$ \\
\hline 16 & EC (millimhos/cm) & $0.8-1.2$ & $0.3-0.6$ \\
\hline 17 & Salinity (ppt) & 1 & $2-4$ \\
\hline 18 & CEC (Meq / 100 g of sample) & $15-20$ & $20-25$ \\
\hline
\end{tabular}

Source: Coir News, 2007 (Coir Board) 
samples were transferred into the reflux unit of the soxhlet extraction apparatus for the first extraction with ethanol: benzene $(2: 1 \mathrm{v} / \mathrm{v})$ for 4 $\mathrm{h}$. The samples were then allowed to dry and the contents transferred to a $400 \mathrm{ml}$ beaker and refluxed in $200 \mathrm{ml}$ distilled water for $4 \mathrm{~h}$.

The cooled samples were then transferred into a $100 \mathrm{ml}$ beaker to which $3 \mathrm{ml}$ of $72 \%$ sulphuric acid was added carefully with the help of a glass road. Another $22 \mathrm{ml}$ of $72 \% \mathrm{H}_{2} \mathrm{SO}_{4}$ was added to make the total volume to $25 \mathrm{ml}$. The sample was then carefully macerated to form a fine paste and kept covered at room temperature for $2 \mathrm{~h}$. The sample was then diluted with distilled water $(575 \mathrm{ml})$ in a one liter beaker and heated on a water bath for $4 \mathrm{~h}$. After cooling the sample was filtered carefully through a clean tarred G-4 sintered Gooch crucible. The residue was washed till free of acid, dried at $105^{\circ} \mathrm{C}$ and weighed till constant reading obtained (B). The net weight recorded and the $\%$ lignin calculated as per the formula \% Lignin $=\mathrm{B} / \mathrm{A} X 100$. All presented results are the mean values in triplicate.

\section{Assays for Enzyme Activity}

The lignin peroxidases (LiP) and manganese peroxidases $(\mathrm{MnP})$ are the enzymes involved in lignin catabolism. The LiP catalyzes the oxidation of non-phenolic aromatic substrates where as MnP catalyzes the oxidation of $\mathrm{Mn}^{2+}$ to $\mathrm{Mn}^{3+}$ (Manganous to manganic), which in turn oxidizes many phenolic substrates [Pandey and Radhakrishnan. 1993]. Hydrogen peroxide is required for the activity of these enzymes. Samples of composted coir pith were drawn from the experimental heap. The extracts of each sample studied by adding sterile water and filtered through Whatman No.1 filter paper. The extract was washed with dilute acid and kept in the deep freeze for 5 minutes. One $\mathrm{ml}$ of acetate buffer $(0.1 \mathrm{M})$ was added to each sample and centrifuged at $8000 \mathrm{rpm}$ for 10 minutes. The supernatant was analyzed for enzyme activity spectrophotometerically using Hitachi UV-Vis. Spectrophotometer. The change in absorbance was observed for 15 minutes. A blank was kept as control.

\section{Assay of lignin peroxide ( $\mathrm{Li} \mathrm{P}$ )}

The reaction mixture containing $2 \mathrm{mM}$ veratryl alcohol $(\mathrm{Km}=60 \mu \mathrm{M}), 0.4 \mathrm{mM} \mathrm{H} \mathrm{O}_{2}$ $(\mathrm{Km}=80 \mathrm{M}), 50 \mathrm{mM}$ tartaric acid and enough ligninase was prepared to give an absorbance change of $0.2 / \mathrm{min}$. One unit of enzyme activity is defined as the quantity of enzyme required for the formation of $1 \mu \mathrm{M}$ of veratryl aldehyde per minute.

\section{Assay of manganese peroxide (Mn P)}

$50 \mathrm{mM}$ sodium tartrate buffer $(\mathrm{pH}-4.5)$ was prepared, $\mathrm{MnSO}_{4}, \mathrm{H}_{2} \mathrm{O}_{2}$ and phenol red at $0.2 \% \mathrm{mM}, 0.1 \mathrm{mM}$ and $0.0025 \%$ concentration respectively to the final volume of $5 \mathrm{ml}$ reaction mixture. The change in absorbance was read at $431 \mathrm{~nm}$. A heat killed enzyme source was maintained as control. One unit of enzyme activity is defined as the amount of enzyme required for 0.1 O.D. change at $431 \mathrm{~nm} / \mathrm{min}$.

\section{Results and Discussion}

A time course study on degradation of coir pith supplemented by biological as well as chemical sources were performed using Pleurotus sajor caju to develop an alternative substitute to urea for accelerating the rate of biodegradation. Chemical analysis reveals that coir pith contains three major constituents' viz., lignin, cellulose, and hemicellulose.

\section{Structure of Lignin}

Lignin is a highly branched, irregular 3dimensional organic polymer, which provides plant strength and resistance to microbial degradation. The enzymology and molecular biology of lignin degradation was well studied by Cullen and Kersten (2004). They described that lignin is a formidable substrate formed through oxidation and free radical coupling of phenyl alcohol precursors (Figure 1). In contrast to hydrolysable bonds between subunits of other wood polymers (eg. cellulose and hemicelluloses), lignin degradation requires oxidative attack on the carbon - carbon and ether inter unit bonds. The lignin polymer encrusts cellulose micro fibrils, particularly within the secondary walls. No microbes, including white rot fungi, are known to be capable of utilizing 
Table 3. Nutrient status of coir pith compost supplemented with urea as nitrogen source

\begin{tabular}{|c|l|c|}
\hline SI No & Chemical composition & Composted coir pith \\
\hline 1 & Lignin (\%) & 16.15 \\
\hline 2 & Cellulose (\%) & 14.81 \\
\hline 3 & Organic Carbon (\%) & 29.6 \\
\hline 4 & Nitrogen (\%) & 1.24 \\
\hline 5 & Phosphorous (\%) & 0.055 \\
\hline 6 & Potassium (\%) & 1.17 \\
\hline 7 & C:N ratio & $22: 1$ \\
\hline 8 & Calcium (\%) & 0.43 \\
\hline 9 & Magnesium (\%) & 0.45 \\
\hline 10 & Copper(ppm) & 6.20 \\
\hline 11 & Iron (ppm) & 0.082 \\
\hline 12 & Manganese (ppm) & 23 \\
\hline 13 & Zinc (ppm) & 13.58 \\
\hline
\end{tabular}

Figure 1. Structure of lignin

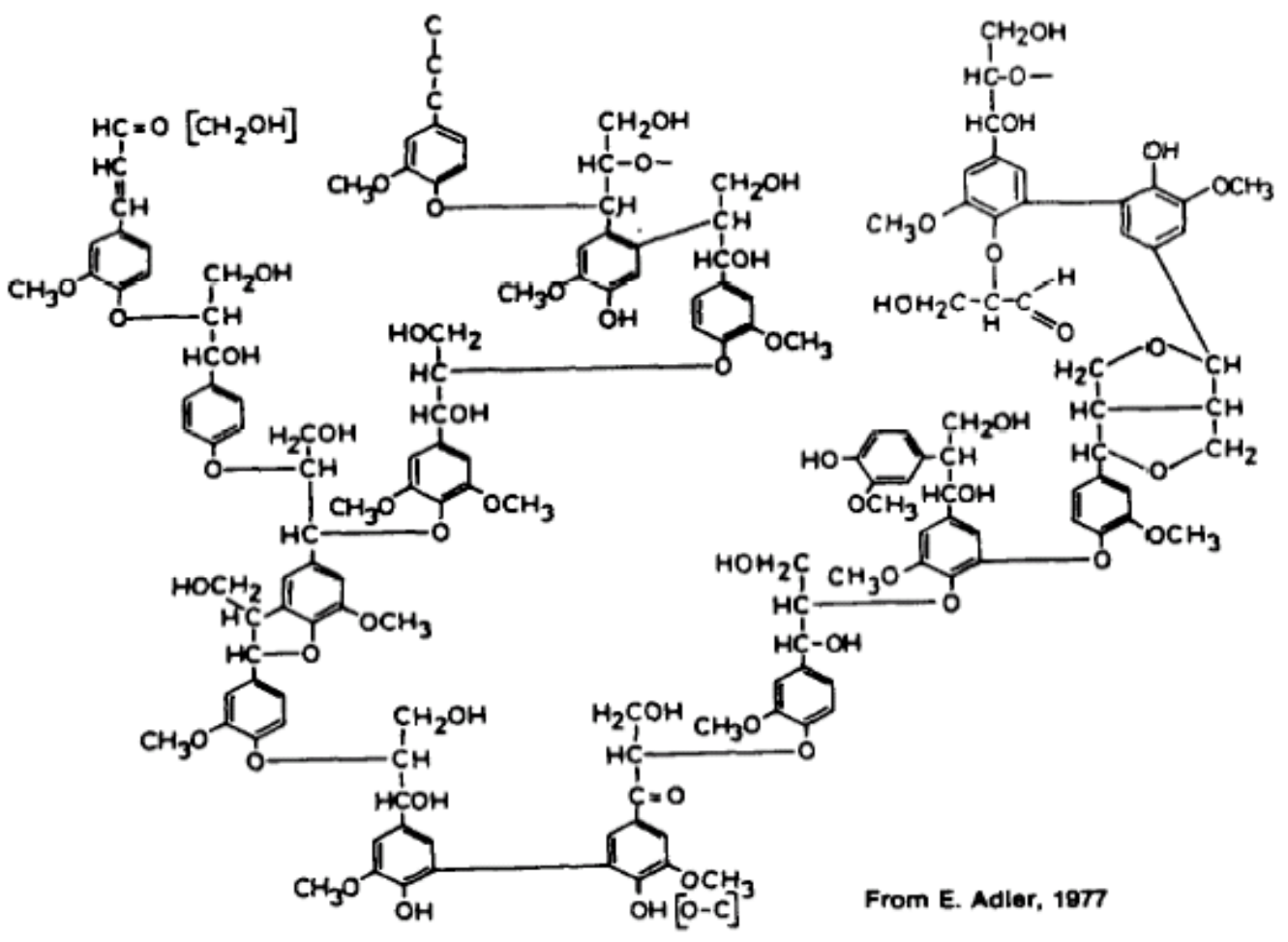


lignin as a sole carbon or energy source. Lignin, are complex plant materials characterized by abezol ring structure with empirical formula, $\mathrm{C}_{42} \mathrm{H}_{32} \mathrm{O}_{6}(\mathrm{OH})\left(\mathrm{OCH}_{3}\right)_{5}$ [Dorothy and Froedrich, 1960]. It has a unit molecular weight of about 800 and is usually associated with harder tissues in plants, including fibres. Lignin prevents the permeation of water, nutrients and metabolites into the internal structure. Among the cellulolytic substances of pith, the hemicellulose contains chains of branched hetero polysaccharides of pentoses and hexoses that are easily amenable to bacterial attack.

\section{Biodegradation of lignin}

Most of the research concerning biodegradation of lignin has been centered on Phanerochaete chrysosporium, Streptomyces viridosporus, Pleurotus eryngii, Trametes trogi and Fusarium proliferatum [De Bertoldi et al 1987]. An excellent review of the decomposition of lignin by wood rotting fungi has been presented by Higuchi [1980]. All lignin degrading microorganisms secrete enzymes such as phenol oxidase in to the substrate [Wood 1979]. The phenol oxidases produced by lignin degrading fungi identical with laccase. Lignin is more readily attacked by fungi than cellulose [Rajarathinam and Zkai 1998], and wood-rotting Basidiomycetes fungi that cause white rot in wood are the most efficient lignin degraders in nature [Akin etal 1995, Higuchi 1980] and they are perhaps nature's major agents for recycling carbon of lignified tissues. No other microorganisms have been described to mineralize the lignified tissues as efficiently [Krik and Farrell, 1987]. The white rot fungi occur naturally as degraders of lignin in fallen trees, ground litter and because lignin is a mixed polymeric compound; these organisms have evolved a wide range of nonspecific enzymatic oxidative systems.

The enzymes from white rot fungi that catalyze the initial depolymerisation of lignin are extra cellular and unusually non specific [Krik and Farrell, 1987]. Lignin degradation by white rot fungi has been extensively studied and the results revealed that the three kinds of extracellullar peroxidases viz., lignin peroxidase
(LiP), manganese peroxidase $(\mathrm{MnP})$ and laccase are responsible for initiating the depolymerisation of lignin in coir pith. Consequences of studies on the fundamental structure-function relationships of $\mathrm{LiP}$ and $\mathrm{MnP}$ are the engineered modification of the enzymes to catalyze new reactions. Manganese binding site has been engineered into LiP H8 [Tien and Krik 1984]. Similarly veratryl alcohol oxidizing activity has been engineered in to MnP by a single amino acid change SI68W [Pudelski 1987].

\section{Ligninolytic enzyme production by P.sajor caju}

Assays to detect the enzymes elicited by Pleurotus sajor caju were conducted using U.VVis. Spectrophotometer at different intervals of $0,5,10$ and 15 minutes. In veratryl alcohol assay, the enzyme elicited by the fungi oxidizes the substrate to veratryl aldehydes. The alcohol exhibits no absorbance at $310 \mathrm{~nm}$, where as the aldehyde absorbs strongly at $310 \mathrm{~nm}$. Manganese peroxidase assay during coir pith degradation is based on the oxidation of phenol red [Tien and Krik 1984]. The principal function of manganese peroxidase (MnP) is to oxidize $\mathrm{Mn}^{2+}$ to $\mathrm{Mn}^{3+}$, using $\mathrm{H}_{2} \mathrm{O}_{2}$ as oxidant [Moriya et al 2001]. Activity of the enzyme is stimulated by simple organic acids which stabilize the $\mathrm{Mn}^{3+}$, thus producing diffusible oxidizing chelates. Manganese peroxidase intermediates are analogous to other peroxidase. The enzyme profile showed variation in abundance with change in substrate, decomposition stage and method of composting.

Lignin loss was slow initially but was observed to increase gradually and thereafter remains more or less constant. When the loss of lignin was maximum, fungi exhibited maximum enzyme activity. Maximum LiP (16.25 U/ml) and $\mathrm{MnP}(20.2 \mathrm{U} / \mathrm{ml})$ activity was detected in P.sajor caju on twentieth day of fermentation using combination of Azolla and Soya hulls as biological source. Activity of LiP was same in conventional composting using urea on twentieth day where as MnP showed an increased profile (20.14 U/ml). Proliferation of fungus on coir pith resulted in lignin loss being degraded steadily 
Figure 2. Ligninolytic enzyme production by $P$. sajor caju using coir pith as the substrate under the supplementation of Azolla and Soya hulls (2:1)

\begin{tabular}{|c|c|c|}
\hline \multirow{2}{*}{ Days } & \multicolumn{2}{|c|}{ Activity } \\
\cline { 2 - 3 } & LiP (U/ml) & MnP (U/ml) \\
\hline 0 & 0 & 0 \\
\hline 2 & 0 & 0 \\
\hline 4 & 0 & 0.5 \\
\hline 6 & 1 & 1.7 \\
\hline 8 & 2.1 & 2.2 \\
\hline 10 & 2.9 & 3.3 \\
\hline 12 & 3.7 & 5.8 \\
\hline 14 & 6.0 & 9.4 \\
\hline 16 & 8.9 & 13.7 \\
\hline 18 & 13.2 & 18.6 \\
\hline 20 & 16.25 & 20.2 \\
\hline 22 & 14.28 & 16.1 \\
\hline 24 & 9.4 & 9.0 \\
\hline 26 & 6.0 & 3.0 \\
\hline 28 & 2.0 & 1.3 \\
\hline 30 & 0.9 & 0.4 \\
\hline
\end{tabular}

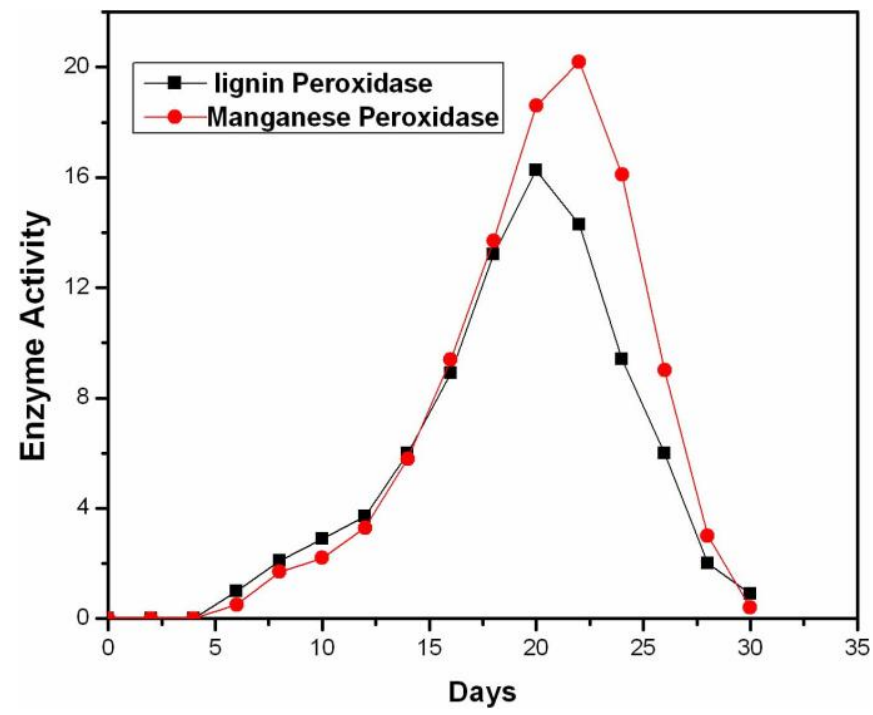

Figure 3. Ligninolytic enzyme production by $P$. sajor caju using coir pith as the substrate (Conventional)

\begin{tabular}{|c|c|c|}
\hline \multirow{2}{*}{ Days } & \multicolumn{2}{|c|}{ Activity } \\
\cline { 2 - 3 } & LiP(U/ml) & MnP(U/ml) \\
\hline 0 & 0 & 0 \\
\hline 2 & 0 & 0 \\
\hline 4 & 0 & 0.48 \\
\hline 6 & 1.2 & 1.68 \\
\hline 8 & 2.4 & 2.13 \\
\hline 10 & 2.9 & 3.28 \\
\hline 12 & 3.9 & 5.73 \\
\hline 14 & 6.2 & 9.39 \\
\hline 16 & 9.1 & 12.9 \\
\hline 18 & 13.4 & 18.3 \\
\hline 20 & 16.25 & 20.14 \\
\hline 22 & 14.31 & 16.8 \\
\hline 24 & 9.61 & 9.4 \\
\hline 26 & 5.94 & 3.3 \\
\hline 28 & 2.2 & 1.4 \\
\hline 30 & 0.89 & 0.41 \\
\hline
\end{tabular}

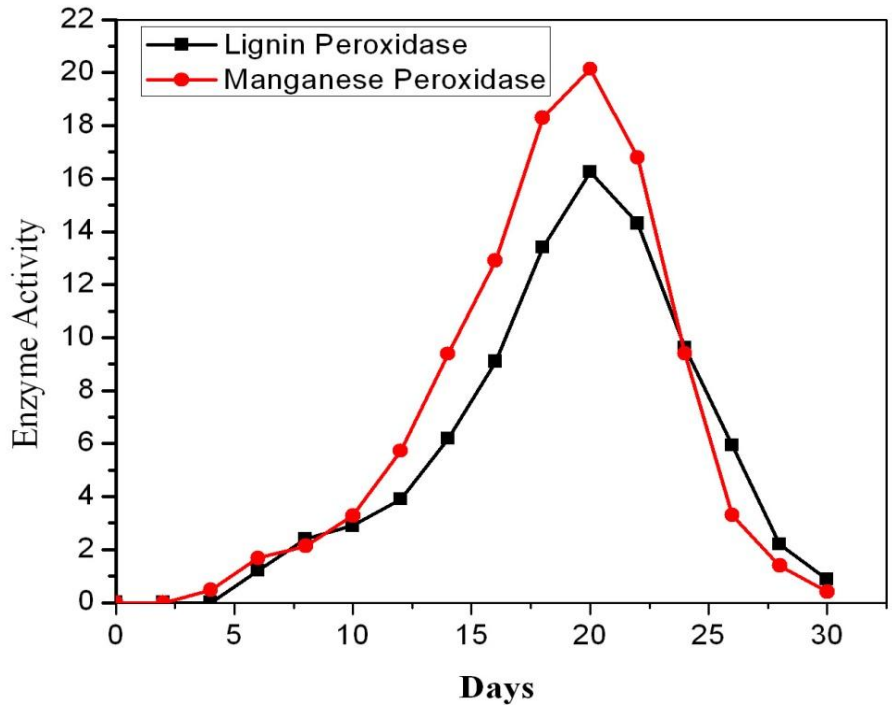


from fifth day and remains maximum on twentieth day $(16.15 \%)$ and thereafter decreased slowly and remains constant. Initial lignin content of raw coir pith was $38.5 \%$ which remains constant in control heaps did not show any activity.

An important finding from the foregoing studies reveals the fact that biodegradation of coir pith supplemented by combinations of Azolla and Soya hulls (2:1) as biological source result in a steep decrease in lignin content from the control value of $38.5 \%$ as in raw coir pith to $16.15 \%$. This is in consistence with the earlier findings of $42 \%$ volume reduction in coir pith during composting by conventional method [Norman and Sinio, 1998, Moorthy 1981]. This could be attributed to the findings of Garcia et al. [1980] who reported that white rot fungi belonging to Basidiomycetes are known to have evolved complex enzymatic machinery to degrade lignin, produce extracellullar polyphenols oxidases particularly lignin peroxidase (LiP), Manganese peroxidase (MnP) and laccases, which are highly effective in degrading lignin.

Studies conducted by Moriya et al. [2001] reveal that extracellullar phenol oxidases produced by the white rot fungi can decompose lignin efficiently during composting. Present studies on assaying the activity of ligninolytic enzymes viz., lignin peroxidase and manganese peroxidase could confirm the activity of the enzymes at regular intervals. The maximum enzyme activity was observed in a combination of Azolla and Soya hulls in 2:1 ratio. This was observed with in the period of 15 to 25 days after inoculation. Further it could be confirmed that the maximum activity of LiP was $16.25 \mathrm{U} / \mathrm{ml}$ and $\mathrm{MnP}$ was $20.2 \mathrm{U} / \mathrm{ml}$ on the twentieth day of inoculation with $P$. sajor caju on coir pith (Figure 2 and 3). Thus it is clear that fungal proliferation on coir pith leads to a reduction in organic carbon and lignin content that commenced steadily from fifth day of inoculation, attained a maximum between fifteenth and twenty fourth day and there after decreased slowly to the minimum. This led to the reduction in lignin content from $38.5 \%$ to $16.15 \%$ in a period of 25 to 30 days.
The colonization of mushroom cause biochemical changes in pith by utilization of cellulose, hemicellulose and lignin that lead to variation in the nutrient status as reported by Wood [1979] and Moorthy [1981]. Rajarathinam \& Zakia [1998] and De Bertoldi et al. [1987] tested the four strains of Pleurotus for the degradation of lignocellulose and $P$. sajor caju showed maximum activities of polysaccharide degrading enzymes which could be correlated to weight loss and reduction in lignin content. In the present study it was observed that Pleurotus sajor caju showed its lignin degradation capability with the production of requisite enzymes. The findings of the present study are in accordance with the observations of earlier findings. Ligninolytic enzymes ( $\mathrm{LiP}$ and $\mathrm{MnP}$ ) can catalyze one electron oxidation of phenolic and non phenolic substrates producing cation radical intermediates. These enzymes oxidize phenolic substrates to reactive phenolic radicals that in turn, can mediate oxidation of nonphenolic substrates. The oxidative enzymes may modify lignin macromolecules by introducing additional functional groups into its structure. These new functional groups may render the lignin more susceptible to subsequent degradation by coordinated action of enzymatic system of the inherent micro flora.

\section{Conclusion}

Microbes that are the natural components of soil and water environments are potential agents for the biological degradation of waste which tends to accumulate in the ecosystem. Coir fibre extraction leads to the accumulation of coir pith which causes environmental pollution. Therefore biodegradation of coir pith is essential to control the pollution caused by its accumulation. The conventional process of coir pith composting using urea has been observed to be efficient in lignin degradation. Urea, an inorganic artificial nitrogen fertilizer when applied leads to the formation of excess ammonia and may immobilize other soil nutrients. The present study leads to the conclusion that coir pith supplemented with natural nitrogen sources viz., Azolla and Soya hulls (2:1), produced an alternative substitute to 
urea for ligninolytic enzyme production during composting of coir pith. The study may also solve the problem of environmental pollution caused by the accumulation of coir pith in the premises of coir fibre extraction units.

\section{Acknowledgements}

Authors are thankful to Shri. V.S. Vijayaraghavan, Ex. MP, Hon. Chairman, Coir Board for his valuable support.

\section{References}

Akin, D.E., Rigsby, L.L. and Sethuraman, A. (1995) Alternations in the structure, and biodegradation of grass lignocelluloses treated with white rot fungi Ceriporiopsis subvermispord and Cyathus stercorius. Appl. Environ. Microbiol. 61: 1591-1598

Cullen, D. and Kersten, P.J. (2004) Enzymology and Molecular Biology of Lignin Degradation. Biochemistry and Molecular Biology. 249-263.

De Bertoldi, M., Ferranti, M.P., L'Hermite, P. and Zucconi, F. (1987) Compost production, Quality and Use. Elsevier Applied Science, London, p.853.

Dorothy, A.B. and Froedrich, E.B. (1960) The Chemistry of lignin.pp7-10, 173-179.

Eriksson, K.E., Blanchette, R.A. and Ander, P. (1990) Microbial and enzymatic degradation of wood and wood components, $3^{\text {rd }}$ edn. Springer, New York, pp.253-305.

Garcia-Martinez, D.V., Shinmyo, Madia, A. and Deman, A. L. (1980) Studies on cellulose production by Clostridium thermocellum. Europ. J. Appl. Microbiol. Biotechnol. 9: 189-197.

Ghosh, P.K., Sarma, U.S., Ravindranath, A.D., Radhakrishnan, S. and Prasenjeet Ghosh (2007) A Novel Method for Accelerated Composting of Coir Pith. Energy Fuels. 21 (2).

Higuchi, T. (1980) Lignin Biodegradation: Microbiology, Chemistry and Potential
Applications. Eds T.K. Kirk. T. Higuchi and Hou-Min Chang. CRC Press, Boca Raton, Florida, p.1.

Kirk, T.K. and Farrell, R.L. (1987) Enzymatic "combustion": the microbial degradation of lignin. Annu. Rev. Microbiol. 41: 465505 .

Muthukumar, G. and Mahadevan (1983) Microbial degradation of lignin. Journal of Scientific and Industrial research. 42: 518-528.

Moriya, O., Yoshimasa, M., Toru, J. and Toshiaki, K. (2001) Lignin degradation and roles of white rot fungi. Study on an efficient symbiotic system in fungus growing termites and its application to bioremediation. Riken Review. 42: 39-42.

Moorthy, K.V. (1981) Microbial and chemical studies on the cultivation of $P$. sajor caju (Fr.) Singer, M. Sc Thesis, University of Agri. Sciences, Bangalore.

Norman Leuis, G. and Sinio Sarknen (1998) Lignin and lignan bio-synthesis. American chemical society: 1-13.

Pandey, A \& Radhakrishnan, S (1993). The Production of Glucoamylase by Aspergillus niger NCIM 1245. Process Biochemistry 28,305-309

Pudelski, T. (1987) In Compost: Production, Quality and Use, eds M. De Bertoldi, M.P. Ferranti, P.L'Hermite and F. Zucconi. Elsevier Applied Science, London, p.20.

Rajarathinam, S. and Zakia, B. (1998) Biodegradative and biosynthetic capabilities of mushrooms: Present and future strategies. Critical Reviews of Biotechnology. 18(2): 91-236.

Stephen, Y.L. and Carlton, W.D. (1992) Methods in lignin chemistry. Springer series in wood sciences.

Tien, M. and Kirk, T.K. (1984) Lignin degrading enzyme from Phanerochaete chrysosporium. Purification and characterization and catalytic properties of 
unique $\mathrm{H}_{2} \mathrm{O}_{2}$ requiring oxygease. Proc. Natl Acad Sci. 81: 2280-2284

Tomati, U., Galli, E., Pasetti, L. and Volterra, E. (1995) Bioremediation of olive-mill wastewaters by composting. Waste Management and Research. 13:509-518

Wood, D.A. (1979) Degradation of composted straw by the edible mushroom. $A$. bisporous. Enzyme activities with mycelia growth and fruit body formation (Ed. Grass word, E) 95-104. 